\title{
PATHS OF RECOVERY: LANDSCAPE VARIABILITY IN FOREST STRUCTURE AND FUNCTION 25 YEARS AFTER THE 1988 YELLOWSTONE FIRES
}

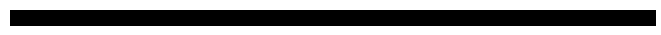

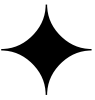 \\ MONICA G. TURNER $\uparrow$ WINSLOW D. HANSEN $\uparrow$ TIMOTHY G. WHITBY \\ UNIVERSITY OF WISCONSIN-MADISON $\downarrow$ MADISON, WI \\ WILLIAM H. ROMME $\uparrow$ COLORADO STATE UNIVERSITY $\uparrow$ FORT COLLINS, CO \\ DANIEL B. TINKER $\uparrow$ UNIVERSITY OF WYOMING $\uparrow$ LARAMIE, WY
}

\begin{abstract}
$\uparrow$ ABSTRACT
Understanding succession following severe wildfire is increasingly important for forest managers in western North America and critical for anticipating the resilience of forested landscapes to changing environmental conditions. Successional trajectories set the stage for future carbon storage, abundance and distribution of fuels, and habitat for many species. Early successional forests are increasing throughout the West in response to greater fire activity, but few long-term studies have considered succession following stand-replacing wildfires over large areas. The size and heterogeneity of the 1988 Yellowstone fires created novel opportunities to study succession at an unprecedented scale following severe fire, and we have studied the consequences of these fires for $>20$ years. In 2012, we began a re-sampling effort in longterm vegetation plots within the area burned by the 1988 fires to answer three overarching questions: (1) Are stand structure and function beginning to converge twenty-five years after the Yellowstone Fires, and what mechanisms may contribute to convergence or divergence? Heterogeneity in forest structure was the rule after the 1988 fires, and postfire lodgepole pine (Pinus contorta var. latifolia) densities ranged from zero to $>500,000$ trees/ha. The post- 1988 cohort of lodgepole pine is reaching a time of critical
\end{abstract}

transitions in structure and function. (2) Are plant community composition and species richness converging or diverging across gradients in local fire severity, post-fire lodgepole pine density, elevation and soil type a quarter-century after the 1988 fires? A central objective in our research has been to understand the relative influence of contingent factors (e.g., local fire severity) vs. deterministic factors (e.g., elevation, soils) on postfire ecosystem development, and how these influences may change through time. (3) How do canopy and surface fuels vary across the postfire landscape, and how will the variation in fuels influence potential fire behavior a quarter century post-fire? Field sampling was conducted for this third question during summer 2012, and data analyses and interpretation are in progress. Overall, results from the proposed study will enhance understanding of succession after one of the most notorious fires of the $20^{\text {th }}$ century. Yellowstone's postfire forests may serve as benchmarks for forests throughout the region and effective sentinels of change for the Rockies.

\section{$\uparrow \quad$ INTRODUCTION}

The 1988 Yellowstone fires ushered in the new era of wildfire in the West. The size and heterogeneity of the fires created novel opportunities 
to study succession and ecosystem processes at an unprecedented scale following severe fire in a wilderness-like setting. We have studied the causes and consequences of these fires for $>20$ years, with a primary focus on understanding postfire succession. To date, we have published $>70$ peer-reviewed articles related to fire in Yellowstone, and our findings have made important contributions to forest management as well as to terrestrial ecology (Turner 2010). The wealth of our early postfire data and potential for having the original researchers resample the long-term study plots offers a unique opportunity to understand succession following one of the most notorious fires of the $20^{\text {th }}$ Century. Yellowstone's postfire forests may be effective sentinels of change for the Rocky Mountains, and our results will provide benchmarks relevant for forests throughout the region.

\section{STUDY AREA}

Our study is being conducted within forests burned by the 1988 fires in Yellowstone National Park (YNP), which encompasses ca. 9,000 $\mathrm{km}^{2}$ in northwestern Wyoming. Stand-replacing fires occur in YNP at 100-300 yr intervals (Schoennagel et al. 2003), but the 1988 fires were remarkable for their severity and size, affecting $36 \%$ of YNP. About $80 \%$ of YNP is dominated by lodgepole pine forest, although subalpine fir (Abies lasiocarpa), Engelmann spruce (Picea engelmannii), and whitebark pine (Pinus albicaulis) can be locally abundant. In these forests, severe fire kills all trees and consumes the shallow litter layer present in unburned forests. Postfire forests in YNP initially had nearly complete cover of bare mineral soil and essentially no duff.

\section{$\uparrow \quad$ METHODS}

During summer 2013, plant community composition was re-sampled in 42 plots in three crown-fire patches that we have studied since 1990 (Turner et al. 1997, 2003). Briefly, we revisited 42 permanently marked sampling plots $(10 \mathrm{~m} \mathrm{x} 1 \mathrm{~m})$ in three crown-fire patches (Cougar Moderate, Fern Large, and Lake Moderate; see Turner et al. 1997). As in our previous sampling campaigns, we identified and tallied all vascular plant species present within each plot.

We re-visited fourteen 0.25 -ha plots to measure inorganic $\mathrm{N}$ availability and litterfall rates (see Turner et al. 2009). Litter traps and resin bags were deployed in 2012 and collected in 2013. Litter was returned to the lab, sorted, dried to constant mass, the mass was recorded, and the litter was subsampled for carbon and nitrogen analysis. We also collected lodgepole pine foliage samples for analysis of foliar chemistry.

We re-sampled aspen in 22 permanent plots in which the height, basal diameter, and density of postfire aspen seedlings have been measured since 1996 (see Romme et al. 2005).

\section{$\downarrow \quad$ PRELIMINARY RESULTS}

Data from the summer 2013 field season have been entered and data analyses are in progress. Preliminary results are summarized briefly here.

Plant community composition. Plant species richness has increased substantially. The total number of species recorded in the subset of 42 plots resampled in 2013 has steadily increased, from 49 species in 1991 to 95 species in 2013. Alpha diversity has increased in all geographic locations, but beta diversity (which reflects plot-to-plot variation) has changed relatively little, suggesting that species have been gaining relatively evenly within the crown-fire patches. Multivariate analyses are in progress.

Postfire ecosystem function. Resin-adsorbed nitrogen $(\mathrm{N})$ averaged $4.1 \mu \mathrm{g}$ nitrate-N/g resin/day (range 0.44 to 12.97 ) and $1.92 \mu \mathrm{g}$ ammonium-N/g resin/day (range 0.54 to 6.43 ) among the fourteen 25 yr old postfire lodgepole pine stands. Total resinadsorbed $\mathrm{N}$ was positively related to total soil $\mathrm{N}(r=$ $0.73, p=0.003)$ and negatively related to soil $\mathrm{pH}(r=$ $-0.61, p=0.02$ ). Current year lodgepole pine foliage averaged $1.33 \% \mathrm{~N}$, ranged from $1.04 \%$ to $1.52 \%$, and declined with increasing lodgepole pine density. Data analyses are in progress.

Postfire aspen size. Aspen seedling height nearly doubled between 1996 and 2013 (from $29.0 \pm$ 1.5 to $58.0 \pm 5.0 \mathrm{~cm}$ ), and basal diameter increased (from $7.0 \pm 0.4$ to $9.7 \pm 0.7 \mathrm{~mm}$.). Aspen height and diameter were positively related to soil $\mathrm{pH}$ and unrelated to lodgepole pine density. Ungulate browsing was high ( $>80 \%$ of seedlings) in 1996 and very low ( $<3 \%$ of seedlings) in 2013 . Aspen results will be presented by W. D. Hansen at the 2014 meeting of the Ecological Society of America.

In addition, one paper based on the 2012 summer field season for this project has been published. Copenhaver and Tinker (2014) reported new allometric equations that predict aboveground 
biomass and aboveground net primary production for 25 -yr old lodgepole pine. These equations will be combined with non-destructive field measurements to calculate stand-level productivity and fuels estimates (as in Turner et al. 2004).

\section{ACKNOWLEDGEMENTS}

This research was funded by the Joint Fire Science Program (JFSP 11-1-1-7) and facilitated by Roy Renkin (Yellowstone National Park). We appreciate the opportunity to access lodging and laboratory facilities at the UW-NPS Research Station for a brief portion of our 2013 field season.

\section{$\uparrow \quad$ LITERATURE CITED}

Brown, J. K. 1974. Handbook for Inventorying Downed Woody Material. General Technical Report INT-16, USDA Forest Service, Forest and Range Experiment Station, Ogden, UT.

Copenhaver, P. E., and D. B. Tinker. 2014. Stand density and age affect tree-level structural and functional characteristics of young, postfire lodgepole pine in Yellowstone National Park. Forest Ecology and Management 320: 138-148.

Romme, W. H., M. G. Turner, G. A. Tuskan, and R. A. Reed. 2005. Establishment, persistence, and growth of aspen (Populus tremuloides) seedlings in Yellowstone National Park. Ecology 86: 404-418.

Schoennagel, T., M. G. Turner, and W. H. Romme. 2003. The influence of fire interval and serotiny on postfire lodgepole pine density in Yellowstone National Park. Ecology 84: 2967-2978.
Simard, M., W. H. Romme, J. M. Griffin, and M. G. Turner. 2011. Do mountain pine beetle outbreaks change the probability of active crown fire in lodgepole pine forests? Ecological Monographs 81:3-24.

Turner, M. G. 2010. Disturbance and landscape dynamics in a changing world. Ecology 91: 2833-2849.

Turner, M. G., W. H. Romme, R. H. Gardner, and W. W. Hargrove. 1997. Effects of fire size and pattern on early succession in Yellowstone National Park. Ecological Monographs 67: 411-433.

Turner, M. G., W. H. Romme, and D. B. Tinker. 2003. Surprises and lessons from the 1988 Yellowstone fires. Frontiers in Ecology and the Environment 1: 351-358.

Turner, M. G., E. A. H. Smithwick, D. B. Tinker, and W. H. Romme. 2009. Variation in foliar nitrogen and aboveground net primary production in young postfire lodgepole pine. Canadian Journal of Forest Research 39: 1024-1035.

Turner, M. G., D. B. Tinker, W. H. Romme, D. M. Kashian, and C. M. Litton. 2004. Landscape patterns of sapling density, leaf area, and aboveground net primary production in postfire lodgepole pine forests, Yellowstone National Park (USA). Ecosystems 7: 751775. 